\title{
TWO COLEOPTEROUS PESTS OF PET FOOD IN PUERTO RICO (FAMILIES CUCUIIDAE AND TENEBRIONIDAE)1
}

Continuing our studies ${ }^{2}$ on the pests of dry pet foods, we give in this note illustrations of two more beetles and correct their names in the list of insects of Puerto Rico.

Wolcott reported Oryzaephilus surinamensis (L.) as "a comon pest of stored food products in Puerto Rico".3 After determining some specimens as that species we sent them to the Agricultural Research Service, USDA, for confirmation. Dr. T. J. Spilman in a letter dated March 18, 1969 wrote, "This is in reply to your letter of March 11th. I identified the accompanying 5 specimens to be the cucujid, Oryzaephilus mercator (Fauvel), the merchant grain beetle. This species has often in the past been confused with $O$. surinamensis (L.), the saw-toothed grain beetle, but the difference between the two is quite obvious: the area behind the eye, the temple, is long in surinamensis, at least equal to half-length of eye, whereas the temple is very short in mercator, almost spine-like. Both species are cosmopolitan pests of stored products".

Which of these two species Wolcott had is not certain. In a letter dated April 24, 1969, Dr. Spilman commented as follows, "I have no information for you on the distribution of Oryzaephilus surinamensis (L.) or mercator (Fauvel) in Puerto Rico or which of the two does indeed occur there. We have no specimens of either from Puerto Rico, and I know only of the citations in Wolcott's Insects of Puerto Rico and Blackwelder's Checklist of the Coleopterous Insects of Mexico, Central America, the West Indies, and South America, Part 3, p. 421 (1945). Because of the confusion of the two species in the past, the citations listed above are almost useless. Both species are cosmopolitan, and both could occur in Puerto Rico. Perhaps the best solution is to disregard past citations and publish new occurrences based on recently identified specimens".

Wolcott $^{4}$ also reported Tribolium castaneum as a pest of various dry foods in Puerto Rico, but erred in spelling the name of the author, Herbst not Herbert. Figure 1 illustrates the immature stages and adults of both species. They were abundant in dry cat food in the old School of Tropical

1 This investigation was supported by Graduate Research Training Grant 5-T01 AI 00015 from the National Institute of Allergy and Infectious Diseases, U. S. Public Health Service.

${ }^{2}$ Moyá Quintana, J. and Fox, I., Alphitobius laevigatus, a pest in Puerto Rico (Coleoptera: Tenebrionidae), J. Agr. Univ. P.R. 44 (1): 181-2, 1970.

${ }^{3}$ Wolcott, G. N., The Insects of Puerto Rico.J. Agr. Univ. P.R. $\$ 2$ (2): 297, 328, 1948.

4 Ibid. 


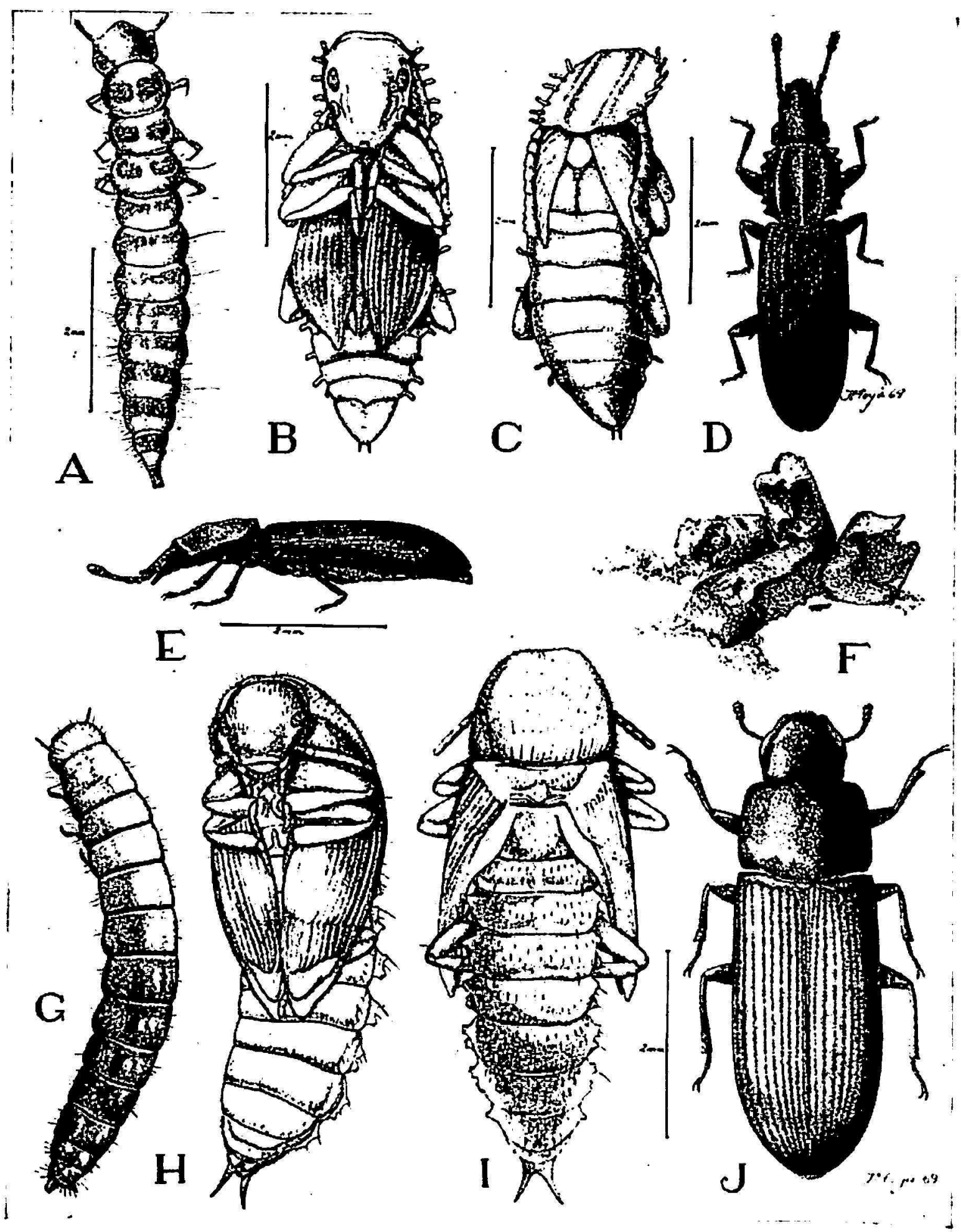

FIG. 1.-Oryzaephilus mercalor (Fauvel). A, Jarva, dorsal view. B, Pupa, ventral view. C, Pupa, dorsal view. D, Adult, dorsal view. E, Adult, lateral view. F, Laboratory chow for rats and mice showing the damage done by Tribolizm castaneum (Herbst). G, Tribolium castaneum (Herbst), larva, dorsal view. H, The same, pupa, ventral view. I, The same, pupa, dorsal view. J, The same, adult, dorsal view. 
Medicine building, Puerta de Tierra, San Juan. We easily established colonies in two brands of commercial dry cat food, in one brand of dry $\operatorname{dog}$ food, and in laboratory chow for rats and mice (fig. 1, F).

Jaime Moya Quintana and Irving Fox

School of Medicine, School of Tropical Medicine

University of Puerto Rico, San Juan, Puerto Rico 


\section{Erratum}

Please note that the first column, Table 4, page 332, in the paper THE EFFECT OF ESTROGEN IN THE ELIMINATION OF SEXUAL ODOR AND ON GROWTH AND CARCASS CHARACTERISTICS IN BOARS, G. Rosado-Carbó et. al., which appeared in J. Agr. Univ. P. R. 53 (4): 329-37, 1969, is in error:

Where it reads Milligrams/gram in italics it should read Micrograms/ gram. 